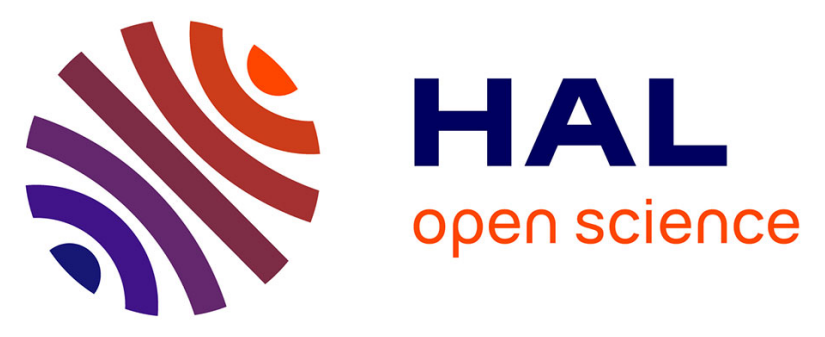

\title{
Spatial and seasonal variation in the prevalence of Anaplasma marginale among beef cattle in previously flooded regions of Thailand
}

Nantiya Saetiewa, Pacharathon Simking, Sinsamuth Saengow, Serge Morand, Marc Desquesnes, Roger W Stich, Sathaporn Jittapalapong

\section{To cite this version:}

Nantiya Saetiewa, Pacharathon Simking, Sinsamuth Saengow, Serge Morand, Marc Desquesnes, et al.. Spatial and seasonal variation in the prevalence of Anaplasma marginale among beef cattle in previously flooded regions of Thailand. Journal of Science and Technology of Agriculture and Natural Resources, 2020, 54 (4), pp.355-362. 10.34044/j.anres.2020.54.4.03 . hal-03101554

\author{
HAL Id: hal-03101554 \\ https://hal.science/hal-03101554
}

Submitted on 16 Nov 2021

HAL is a multi-disciplinary open access archive for the deposit and dissemination of scientific research documents, whether they are published or not. The documents may come from teaching and research institutions in France or abroad, or from public or private research centers.
L'archive ouverte pluridisciplinaire HAL, est destinée au dépôt et à la diffusion de documents scientifiques de niveau recherche, publiés ou non, émanant des établissements d'enseignement et de recherche français ou étrangers, des laboratoires publics ou privés. 
Research article

\section{Spatial and seasonal variation in the prevalence of Anaplasma marginale among beef cattle in previously flooded regions of Thailand}

Nantiya Saetiew ${ }^{\mathrm{a}, \mathrm{b}, \mathrm{c}}$, Pacharathon Simking ${ }^{\mathrm{a}, \mathrm{b}, \mathrm{d}}$, Sinsamuth Saengow ${ }^{\mathrm{d}}$, Serge Morand ${ }^{\mathrm{e}, \mathrm{h}}$, Marc Desquesnes ${ }^{\mathrm{f}}$, Roger W Stich ${ }^{\mathrm{g}}$, Sathaporn Jittapalapong ${ }^{\mathrm{a}, \mathrm{b}, \mathrm{h}, *}$

a Center for Agricultural Biotechnology, Kasetsart University, KamphaengSaen Campus, Nakhon Pathom 73140, Thailand.

${ }^{b}$ Center of Excellence on Agricultural Biotechnology, Science and Technology Postgraduate Education and Research Development Office, Commission on Higher Education, Ministry of Education. (AG-BIO/PERDO-CHE), Nakhon Pathom 73140, Thailand.

c Department of Animal Science, Faculty of Science and Technology, Muban Chombueng Rajabhat University, Ratchaburi 70150, Thailand.

d Division of Animal Health Science, Faculty of Agricultural Technology, Rajamangala University of Technology Thanyaburi, Pathum Thani 12110, Thailand.

- CNRS ISEM - CIRAD - ASTRE, Campus International de Baillarguet, Montpellier, France.

${ }^{f}$ CIRAD-Bios, UMR InterTryp, Campus International de Baillarguet, Montpellier, France.

$g$ Department of Veterinary Pathobiology, University of Missouri, Columbia, Missouri, USA.

${ }^{h}$ Faculty of Veterinary Technology, Kasetsart University, Bangkok 10900, Thailand.

\section{Article Info}

\section{Article history:}

Received 18 June 2019

Revised 15 October 2019

Accepted 29 November 2019

Available online 31 August 2020

\section{Keywords:}

Anaplasma marginale,

Epidemiology,

Flooding,

PCR,

Seasonality

\begin{abstract}
Anaplasma marginale is the primary etiologic agent of bovine anaplasmosis, an important vectorborne disease among livestock worldwide including Thailand. The objective of this study was to measure the seasonal effect on A. marginale distribution among cattle in northern (Nan), central (Nakhon Sawan) and southern (Ayutthaya) parts of the Chao Phraya river basin in Thailand, which was devastated by flooding in 2011. Bovine blood samples were randomly collected during dry (November-December 2012; n=241) and rainy (May-June 2013; n=328) seasons. Both microscopy and molecular assays were employed to identify infected samples. Generalized Linear Mixed Models (GLMMs) were used to test putative risk factors for association of $A$. marginale infection with sampling location, herd size, age, sex and season. The overall prevalence of A. marginale was $14.9 \% \pm 5 \%(36 / 241)$ during the dry season and $23.2 \% \pm 5 \%(76 / 328)$ during the rainy season. Nakhon Sawan had a high and stable prevalence (approximately 30\%), while Nan and Ayutthaya had increased prevalence in the rainy season (20 and 23.2\%, respectively) compared with the dry season (2.9 and $7.8 \%$, respectively). Prevalence of 25.7 to $29.8 \%$ was observed among $80 \%$ of large herds sampled, while 20 (dry season) to $63 \%$ (rainy season) of the animals were infected among $23 \%$ of the small herds. The GLMM analysis revealed the importance of sampling location, herd size, season and the interaction between sampling location and season, which have key roles in A. marginale infection of cattle.
\end{abstract}

\footnotetext{
* Corresponding author

E-mail address: fvetspj@ku.ac.th (S. Jittapalapong)

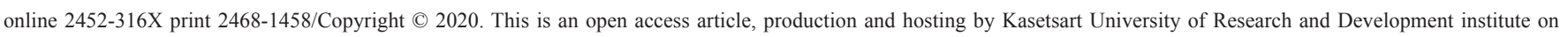
behalf of Kasetsart University.

https://doi.org/10.34044/j.anres.2020.54.4.03
} 


\section{Introduction}

Bovine anaplasmosis is an important hemoparasitic disease with a severe impact on livestock production in developing countries. The etiologic agent of this disease, Anaplasma marginale (order Rickettsiales, family Anaplasmataceae), multiplies within intraerythrocytic parasitophorous vacuoles known as marginal bodies. Infected erythrocytes are subsequently removed by the host reticuloendothelial system, resulting in severe anemia and jaundice, but without hemoglobinemia or hemoglobinuria (Dumler et al., 2001). Other clinical signs may include weight loss, decreased milk production, abortion and sudden death (Richey and Palmer, 1990). Anaplasma marginale is biologically transmitted by rhipicephaline ticks, and can be mechanically transmitted by biting flies or bloodcontaminated fomites (Kocan et al., 2003).

A conventional approach to diagnosis of clinical bovine anaplasmosis involves microscopic observation of intraerythrocytic marginal bodies in stained blood smears. However, microscopic detection of $A$. marginale is difficult in subclinical animals or persistently infected carriers with low parasitemias. PCR-based assays were developed as alternative methods for epidemiological investigations of Anaplasma spp. infections (de la Fuente et al., 2005a; Carelli et al., 2007). Several useful PCR assays for Anaplasmataceae are based on outer membrane protein gene sequences that are both specific and conserved at the species level, thus allowing design of optimally sensitive primers for specific targets (Stich et al., 2002). Similarly, Anaplasma major surface protein (MSP) genes that are subject to host immune selective pressures, such as $m s p 4$, have proven useful for epidemiologic and phylogenetic studies of $A$. marginale (de la Fuente et al., 2005a; 2005b) as well as detection of anaplasmal infection (Guglielmone, 1995).

Bovine anaplasmosis has been reported for more than five decades in Thailand, where it causes significant economic losses in livestock production (Watanasin, 1965; Arunyakanon et al., 1966; Jittapalapong and Lieowijak, 1988; Chethanond et al., 1995; Fungfuang et al., 2006; Worasing and Rattana, 2007; Yawongsa et al., 2010). During the rainy season, flies and ticks significantly increase in number, thereby increasing the possibility of $A$. marginale transmission and biological amplification in the environment (Melendez and Forlano, 1997). However, Thailand suffered major flooding over $70 \%$ of the country in 2011, particularly near the Chao Phraya River, including the provinces of Nan, Nakhon Sawan and Ayutthaya. These floods altered the local environment, affecting vector ecology and habitats that in turn could affect transmission of vector-borne pathogens such as $A$. marginale. The purpose of this study was to investigate the seasonal effect on $A$. marginale infections of cattle in these recently flooded provinces.

\section{Materials and Methods}

\section{Study areas}

Nan, Nakhon Sawan and Ayutthaya provinces were chosen as areas that were flooded in 2011. Nan is located on the Nan River, a tributary of the Chao Phraya River, while Nakhon Sawan and Ayutthaya are situated on the Chao Phraya River. These three provinces were flooded to different degrees depending on their landscape in 2011. Fig. 1 illustrates the Chao Phraya River Basin, and the blue-gray color on the map indicates provinces that were severly flooded in 2011 (Thaipadungpanit et al., 2013).

\section{Seasonal factors}

Seasons affect humidity and temperature, influencing vector habitats and possibly the infections they transmit. Recently, the timing and lengths of these seasons have become inconsistent due to climate change (Zhang et al., 2008). As this study was designed to collect samples during the rainy and dry seasons, to compare seasonal effects, samples collected from November to December 2012 ( $n=241)$ were assigned to the dry season, while samples collected from May to June $2013(n=328)$ were assigned to the rainy season.

\section{Blood samples and parasitological examination}

Blood samples $(n=569)$ were collected from beef cattle between November 2012 and June 2013, using the multistage cluster random sampling technique (McBurney and White, 2010). Animals were bled from the jugular vein into sterile tubes containing EDTA as an anticoagulant. Blood smears were processed at the collection sites. Blood samples were packed in ice box and shipped everyday by night transportation to the Department of Parasitology, Faculty of Veterinary

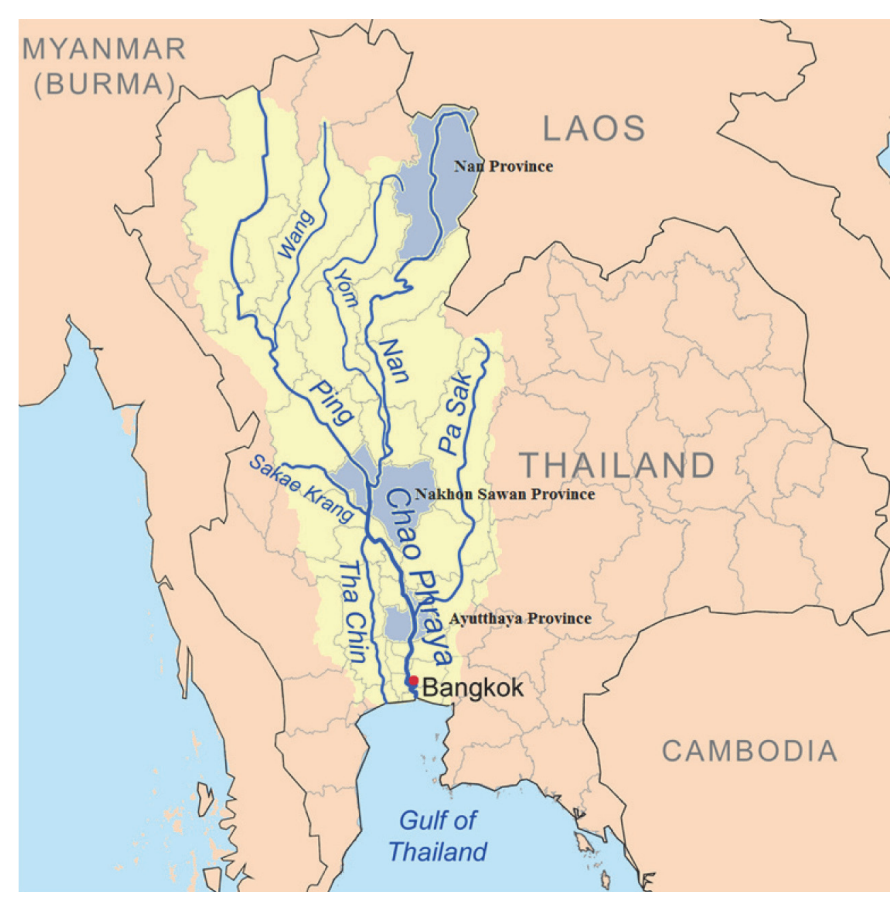

Fig. 1 A map illustrating the Chao Phraya River system of Thailand.Yellow color represents the Chao Phraya River Basin, and blue-gray color on the map indicates provinces that were severely flooded in 2011 (Thaipadungpanit et al., 2013). 
Medicine, Kasetsart University, and stored at $-20^{\circ} \mathrm{C}$ until assayed with PCR. Pertinent information about the animals was recorded, including age, sex, and herd size. The number of animals sampled on each ranch was based on herd size. All heads were bled for herd sizes between 1 to 20 , while 20 head were bled for herd sizes greater than 20 . There were 36 farms in this study divided into 15 large and 21 small herds. In dry season, there were 13 small and 7 large herds while in rainy season, there were 8 small and 8 large herds. The location of animal samples was recorded using GPS and attempt to use the same animal or nearby animals with the range of GPS during dry and raining season collection. However, beef cattle was not reared last long due to their owners' need. Therefore, we can not use the same animals by the time of the second blood collection. The criteria of sampling animals were depend on the fact that each (large or small) farms had the number of selected animals (such as age, healthy, and gender). The number of animal for each farm was varied between dry and raining season.

Blood smears were prepared with fresh blood, fixed in methanol, and stained with Giemsa. Microscopic examination $(1000 \times)$ was carried out on 50 fields per slide (approximately 50 RBCs per field) of Giemsa-stained blood smears.

\section{Molecular detection of A. marginale}

\section{DNA extraction}

A total of $500 \mu \mathrm{L}$ of denaturing solution (4 M guanidiniumthiocyanate, $25 \mathrm{mM}$ sodium citrate, $\mathrm{pH}$ 7, $0.1 \mathrm{M}$ 2-mercaptoethanol, and $0.5 \%$ N-lauroylsarcosine) was added to each $1 \mathrm{~mL}$ blood sample. Proteins were extracted by the phenol-chloroform method, and DNA precipitated with salt and ethanol (Sambrook et al., 1989); dried DNA pellets were dissolved in a Tris-EDTA buffer $(50 \mathrm{mM}$ Tris, $\mathrm{pH}$ 8.0, 1mM EDTA). DNA concentrations were measured by spectrophotometry with a Nano Drop ND2000 (Thermo Scientific, USA) and stored at $-20^{\circ} \mathrm{C}$ until use.

\section{msp4-based PCR assay}

Primers MSP43 (5'-CCGGATCCTTAGCTGAACAGGAA TCTTGC-3') and MSP45 (5'-GGGAGCTCCTATGAATTACA GAGAATTGTTTAC-3') were used to amplify an approximately 850 bp fragment of the A. marginale Major Surface Protein 4 gene (msp4) (de la Fuente et al., 2005b). No-template controls were used every 10 samples, to ensure the absence of contamination. The first PCR-positive sample, which was confirmed with sequence analysis, was subsequently used as the positive control. The msp4-based 850 bp fragment was amplified from $2 \mu \mathrm{L}$ (approximately $100 \mathrm{ng}$ ) of total DNA by PCR. The PCR conditions consisted of a $20 \mu \mathrm{L}$ PCR reagent mixture, $1 \mathrm{pmol} / \mu \mathrm{L}$ of each primer, $0.2 \mathrm{mM}$ deoxynucleotide triphosphates, $1.0 \mathrm{mM} \mathrm{MgCl}_{2}, 0.5$ unit of Taq DNA polymerase and $1 \mathrm{X}$ PCR buffer (200 mM Tris-HCl, pH 8.4, $500 \mathrm{mM} \mathrm{KCl}$ ) (Invitrogen $^{\mathrm{TM}}$, Brazil) in $0.2 \mathrm{ml}$ PCR tubes. Reactions were performed in a T1 Thermocycler (Biometra, Germany) for 40 cycles. After an initial denaturation step of 2 min at $95^{\circ} \mathrm{C}$, each cycle consisted of a denaturation step of $30 \mathrm{sec}$ at $95^{\circ} \mathrm{C}$, an annealing step of $30 \mathrm{sec}$ at $60^{\circ} \mathrm{C}$, and an extension step of $1 \mathrm{~min}$ at $72^{\circ} \mathrm{C}$. PCR products were electrophoresed on 1\% agarose gels. Amplicon-positive PCR products were purified for sequencing.

\section{PCR product purification}

After electrophoresis, the desired DNA band was cut from the agarose gel and melted irreversibly in a chaotropic salt solution. The DNA was then bound to Ultra Bind ${ }^{\circledR}$ silica particles in the presence of Ultra Salt ${ }^{\mathbb{R}}$. The DNA/silica complex was pelleted in a microcentrifuge, and the melted gel was discarded. The pellet was washed once and the concentrated DNA was collected in $\mathrm{ddH}_{2} \mathrm{O}$.

\section{Sequence analysis}

Purified PCR products were sent to the BioService Unit, NSTDA (Bangkok, Thailand) for DNA sequencing, and BLAST analysis (NCBI) was used to identify the sequences obtained.

\section{Statistical analysis}

Qualitative PCR results for A. marginale were analyzed with factors including sex, age, herd size, and location. The Chi-square and Number Cruncher Statistical System (NCSS) ver. 2000 (Kaysville, UT) programs were used to assess differences in the prevalence and intensity of infection. Comparisons were conducted between sexes (male, female), age groups ( $<1$ year, $1-5$ years, $>5$ years), provinces and herd sizes. A comparison between seasonal results was assessed by calculating a statistic at $95 \%$ confidence. The results were compared using a software program (Win Episcope, version 2.0). To analyze the infection of cattle, we modeled the positive/negative PCR results for A. marginale as a function of sex, age, herd size, season and location with a general linear mixed model (GLMM with logit function) using package lme4 implemented in $\mathrm{R}$. The initial model also included all interaction terms between explanatory variables. To avoid a potential farm effect, farm identity was used as a random factor. Support for competing models was evaluated by investigating the relationship between the prevalence of $A$. marginale and all explanatory variables of interest (sex, age, herd size, season and province location) and farm identity as r. Likelihood-based methods were used to quantify alternative models and to estimate their parameters. AIC adjusted for sample size (AICc) was used to assess the relative information content of the models. The uncertainty of the "best" model was quantified so that it would emerge as superior if different data were used with Akaike weights wr. Selection of the best competing models was made using package glmulti version 1.0.7 (Calcagno et al., 2010), implemented in $\mathrm{R}$, which allowed the exploration of all models using automated model selection and model-averaging procedure with a genetic algorithm.

\section{Animal ethics}

Animal care and all experimental procedures were approved by the Animal Experiment Committee, Kasetsart University, Thailand (approval No. ACKU60-VTN-011) and conducted according to the Regulations on Animal Experiments at Kasetsart University. 


\section{Results}

In total, 569 bovine blood samples were collected from the three provinces (Nan, $\mathrm{n}=185$; Nakhon Sawan, $\mathrm{n}=191$ and Ayutthaya, $\mathrm{n}=193$ ) in Thailand. The msp4-specific primers were used to generate 849-bp amplicons (Fig. 2), which were identified as $A$. marginale through sequence analysis. The prevalence of $A$. marginale by the PCR and microscopic techniques is shown in Table 1. Out of 569 animals, 112 (19.7\%) were PCR-positive for A. marginale. Microscopic examination of 384 Giemsa-stained blood smears revealed limited numbers of erythrocytes harboring marginal bodies, which were only observed in 20 samples. Microscopically, parasitemia was generally low (less than 1 infected erythrocyte/microscopic field) with the highest level at 3-5 parasites/field (Fig. 3).

As expected, the PCR test was more sensitive than microscopic examination alone. All the microscopy-positive samples were also PCR-positive, while 67 of 87 PCR-positive samples were negative by microscopic examination. Interestingly, of the two seasons studied in these three provinces (Table 2), the highest prevalence of $A$. marginale among individual cattle was in Nakhon Sawan $(33.3 \%, 27 / 81)$ during the dry season $(p<0.05)$. However, as expected, higher $A$. marginale prevalence was observed during the rainy season (Table 2) in Nan $(p<0.05)$ and Ayutthaya $(p<0.05)$.

At the farm level, A. marginale was detected in $23 \%$ of small herds ( $<20$ cattle, which was significantly less than the $80 \%$ of large herds $(\mathrm{n}>20$ head) $(p<0.05)$ (Table 2). Out of 569 samples originating from 36 farms, 112 were PCR-positive (19.7\%), belonging to 17 farms (i.e., $47.2 \%$ of the farms sampled contained at least one infected host); thus, 359 cattle were exposed to infected animals (63.1\% of the population sample). The prevalence on these 17 infected farms was $31.2 \%$ (112/359). Interestingly, cattle aged $1-5$ years had the highest prevalence of detectable $A$. marginale infections $(39.74 \%$; $93 / 234$ ), while the age group with the lowest detectable prevalence was cattle over 5 years old $(18.42 \% ; 7 / 38)$. The effect of sex for $A$. marginale infection was not statistically significant (Table 2).

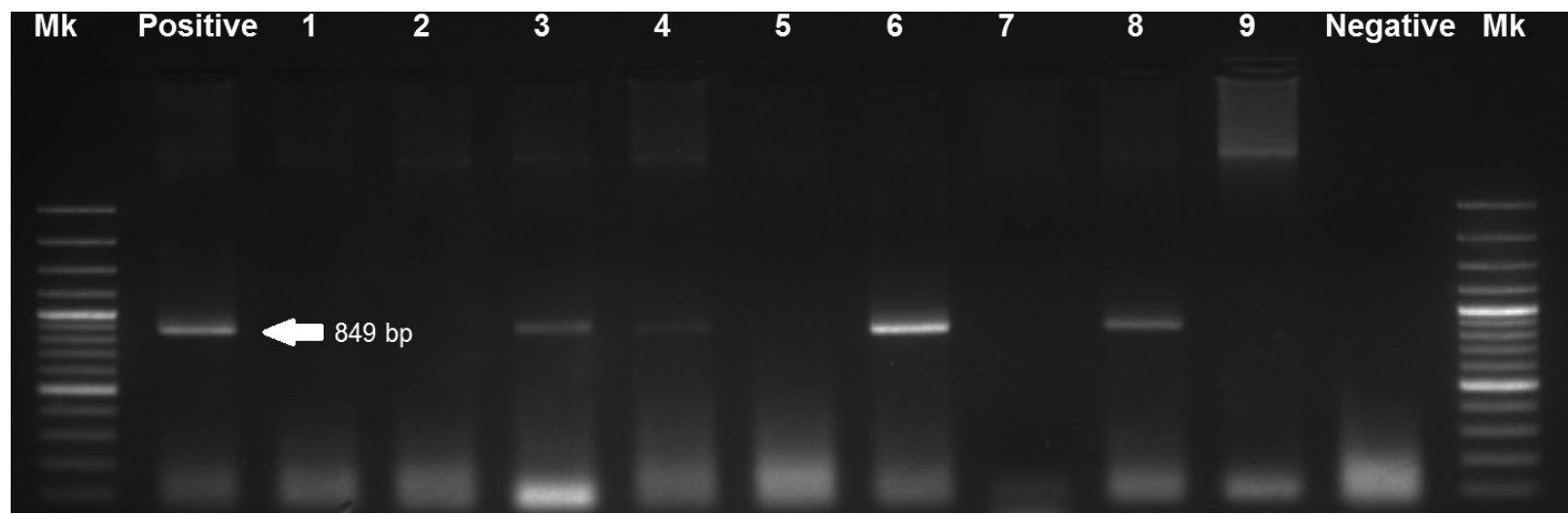

Fig. 2 Detection of A. marginale with the msp4-based PCR assay. Mk (extreme right and left lines): 100-bp ladder molecular size standard; Positive: A. marginale positive control ( $849 \mathrm{bp}$ ) from a naturally infected host; Lanes 1-9: field samples (lanes 3, 4, 6 and 8 contain 849 bp PCR-positive bands); Negative: the no-template negative control.

Table 1 Prevalence of A. marginale established by GSBS and msp4 gene PCR

\begin{tabular}{llcc}
\hline Province & $\mathrm{n}$ & GSBS positive (\%) & PCR positive (\%) \\
\hline Nan & 185 & ND & $25(13.51 \%)$ \\
Nakhon Sawan & 191 & $12(6.28 \%)$ & $57(29.84 \%)$ \\
Ayutthaya & 193 & $8(4.15 \%)$ & $30(15.54 \%)$ \\
\hline
\end{tabular}

GSBS: Giemsa-stained blood smear; ND: Not Determined

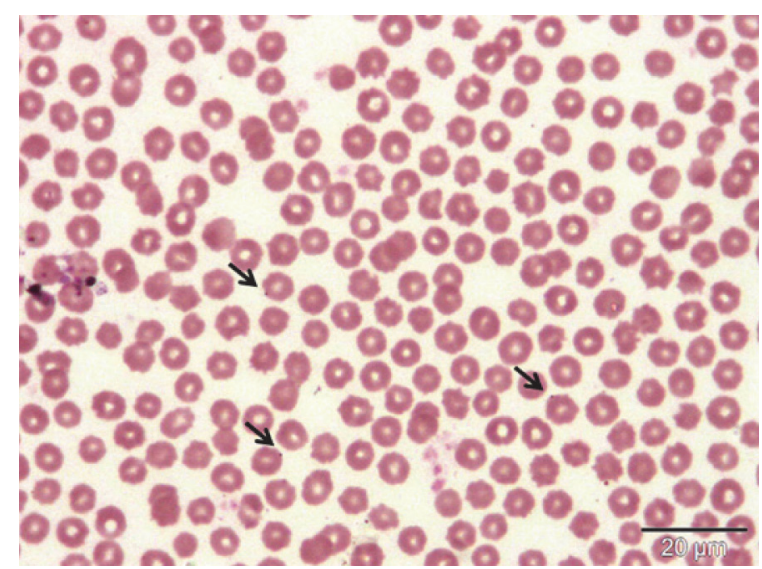

Fig. 3 Light micrograph (magnification 1,000×) of a Giemsa-stained bovine blood smear with erythrocytes containing marginal bodies indicative of infection with Anaplasma marginale (arrows). Bar $=20 \mu \mathrm{m}$. 
Table 2 Comparison of prevalence and factors associated with A. marginale infection in cattle between dry and rainy season

\begin{tabular}{|c|c|c|c|c|}
\hline \multicolumn{2}{|l|}{ Parameter } & \multirow[t]{2}{*}{ Dry season } & \multicolumn{2}{|l|}{ Rainy season } \\
\hline \multirow[t]{5}{*}{ Individual Prevalence } & Province & & & \\
\hline & Nan & $2 / 70 ; 2.9 \% \pm 4 \%$ & $23 / 115 ; 20.0 \% \pm 7 \%$ & $25 / 185 ; 13.51 \% \pm 4.9 \%, \mathrm{P}=0.001$ \\
\hline & Nakhon Sawan & $27 / 81 ; 33.3 \% \pm 10 \%$ & $30 / 110 ; 27.3 \% \pm 8 \%$ & $57 / 191 ; 29.84 \% \pm 6.5 \%, \mathrm{P}=0.366$ \\
\hline & Ayutthaya & $7 / 90 ; 7.8 \% \pm 6 \%$ & $23 / 103 ; 22.3 \% \pm 8 \%$ & $30 / 193 ; 29.13 \% \pm 5.6 \%, \mathrm{P}=0.005$ \\
\hline & Total & $\begin{array}{l}36 / 241 ; 14.9 \% \pm 5 \% \\
\mathrm{df}=2, \chi 2=33.24, \mathrm{P}=0.001\end{array}$ & $\begin{array}{l}76 / 328 ; 23.2 \% \pm 5 \% \\
d f=2, \chi 2=1.73, P=0.421\end{array}$ & $112 / 569 ; 19.68 \% \pm 3.2 \%, \mathrm{P}=0.014$ \\
\hline \multirow[t]{6}{*}{ Farm prevalence ${ }^{1 /}$} & Size & & & \\
\hline & Small $(\mathrm{n}<20)$ & Pisf $=2 / 13 ; 15 \%$ & Pisf $=3 / 8 ; 37 \%$ & Pisf $=5 / 21 ; 23 \%$ \\
\hline & & Piasf $=2 / 10 ; 20 \% \pm 3 \%$ & Piasf $=21 / 33 ; 63 \% \pm 17 \%$ & Piasf $=23 / 43 ; 53.5 \% \pm 14.9 \% ; P=0.02$ \\
\hline & Large $(n \geq 20)$ & Pilf $=6 / 7 ; 86 \%$ & Pilf $=6 / 8 ; 75 \%$ & Pilf $=12 / 15 ; 80 \%$ \\
\hline & & Pialf $=34 / 132 ; 25.7 \% \pm 7.5 \%$ & Pialf $=55 / 184 ; 29.8 \% \pm 6.6 \%$ & Pialf $=89 / 316 ; 28.2 \% \pm 5 \% ; P=0.424$ \\
\hline & & $\mathrm{df}=1, \chi^{2}=0.162, \mathrm{P}=0.686$ & $\mathrm{df}=1, \chi^{2}=14.001, \mathrm{P}=0.001$ & \\
\hline \multirow[t]{4}{*}{$\operatorname{Age}^{1 /}$} & $<1$ year & $11 / 41 ; 26.83 \% \pm 14.1 \%$ & $1 / 9 ; 11.11 \% \pm 25.6 \%$ & $12 / 50 ; 24.0 \% \pm 12 \%, \mathrm{P}=0.317$ \\
\hline & $1-5$ years & $21 / 41 ; 51.2 \% \pm 10 \%$ & $72 / 193 ; 37.30 \% \pm 6.8 \%$ & $93 / 234 ; 39.74 \% \pm 5 \%, \mathrm{P}=0.103$ \\
\hline & $>5$ years & $4 / 23 ; 17.39 \% \pm 16.7 \%$ & $3 / 15 ; 20 \% \pm 22.9 \%$ & $7 / 38 ; 18.42 \% \pm 13 \%, \mathrm{P}=0.839$ \\
\hline & & $36 / 142 ; 25.35 \% \pm 7.2 \%, \mathrm{P}=0.631$ & $76 / 217 ; 35.02 \% \pm 6.3 \%, \mathrm{P}=0.123$ & \\
\hline \multirow[t]{3}{*}{$\operatorname{Sex}^{1 /}$} & Male & $25 / 92 ; 27.17 \% \pm 9.26 \%$ & $59 / 176 ; 33.52 \% \pm 7.04 \%$ & $84 / 268 ; 31.34 \% \pm 5 \%, \mathrm{P}=0.287$ \\
\hline & Female & $11 / 50 ; 22 \% \pm 11.8 \%$ & $17 / 41 ; 41.46 \% \pm 15.7 \%$ & $28 / 91 ; 30.76 \% \pm 12 \%, \mathrm{P}=0.06$ \\
\hline & & $36 / 142 ; 25.35 \% \pm 7.2 \%, \mathrm{P}=0.493$ & $76 / 217 ; 35.02 \% \pm 6.3 \%, \mathrm{P}=0.337$ & $\mathrm{df}=1, \chi 2=0.001, \mathrm{P}=0.977$ \\
\hline
\end{tabular}

1/Comparative prevalence of infected farms and infected animals in the dry and rainy seasons

Pifs=prevalence of infected small farms; Pilf= prevalence of infected large farms; Piasf=Prevalence of infected animals on small farms; Pialf=Prevalence of infected animals on large farms

Among all competeing GLMMs analyzed with glmulti (Calcagno et al., 2010), four explanatory variables were selected among 100\% of A. marginale infection models (Fig. 4). These variables were province, herd size, season and the interaction between province and season, which were observed in the three best top models (Table 3 ). Focusing on the first best top model, it appeared that $A$. marginale infection was more likely (1) in cattle from Nan than Ayutthaya, (2) during the rainy season and (3) in farms with large herds.

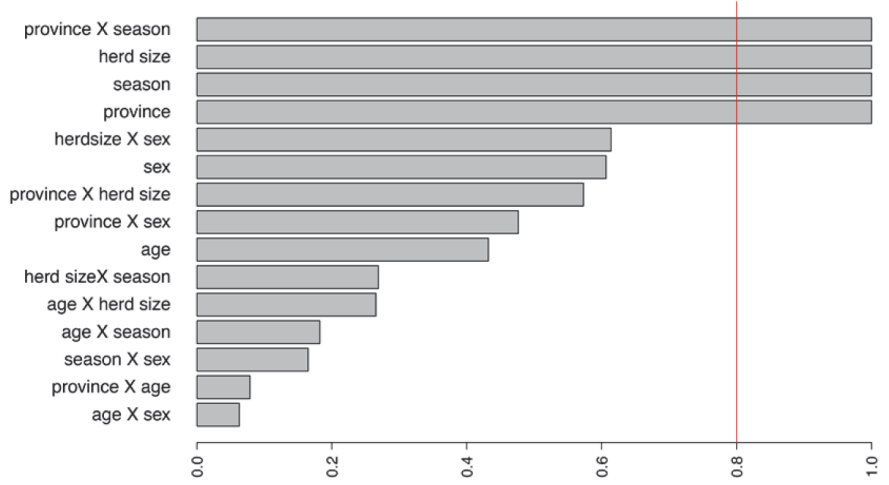

Fig. 4 Results of GLM model-averaged importance of explanatory variables and their interactions in explaining the infection by Anaplasma marginale. The threshold at $0.80(80 \%)$

Table 3 Comparison of the best GLMM models (with logit link function, and locality as a random factor) explaining A. marginale infection (positive PCR). The initial model included the following explanatory variables: The initial model included the following explanatory variables: sex, age, herd size, season, location and all interaction terms, with farm as random variable. Models are ranked from lowest to highest supported according to corrected Akaike information criteria (AIC) ( $K$ is the number of estimated parameters, Log-lik is the maximized value of the logarithm of the likelihood function, AICc the selection criterion, and the Akaike weights)

\begin{tabular}{|c|c|c|c|c|}
\hline Models (best top 3) & $K$ & Log-lik & $\mathrm{AICc}$ & $\mathrm{W}_{\mathrm{r}}$ \\
\hline province + season + herd size & 6 & -235.9 & 515.90 & 0.039 \\
\hline \multicolumn{5}{|l|}{+ season $\mathrm{X}$ Province + province $\mathrm{X}$ herd size } \\
\hline province + season + sex + herd size & 10 & -228.7 & 516.34 & 0.032 \\
\hline \multicolumn{5}{|l|}{+ season $\mathrm{X}$ province + sex $\mathrm{X}$ province } \\
\hline \multicolumn{5}{|l|}{+ province $\mathrm{X}$ herd size + season $\mathrm{X}$ herd size } \\
\hline \multicolumn{5}{|l|}{+ sex X herd size } \\
\hline province + season + sex + herds size & 9 & -232.1 & 516.35 & 0.031 \\
\hline \multicolumn{5}{|l|}{+ season $\mathrm{X}$ province + sex $\mathrm{X}$ province } \\
\hline+ province $\mathrm{X}$ herd size + sex $\mathrm{X}$ herd size & & & & \\
\hline
\end{tabular}




\section{Discussion}

In Nan, the prevalence of $A$. marginale was found to be $2.9 \pm 4 \%$ $(2 / 70)$ and $20 \pm 7 \%(23 / 115)$ in the dry and rainy seasons, respectively. Comparatively, Teerapat and Dissamam (1965) reported A. marginale prevalence at $40.0 \%(16 / 40)$ in Nan province. Nan is a mountainous province where the Nan River originates, and where flash flooding might have less effect on vectors of $A$. marginale. Thus, the seasonal effect observed in Nan, measured as the increased prevalence of A. marginale during the rainy season, could be associated with an increase in mechanical vector populations and higher population density of ticks due to higher humidity during the rainy season (Islam et al., 2006; Mohanta et al., 2011; Torti, 2012). Consequently, the rainy season could have favored ticks and blood sucking flies, leading to the high prevalence and density, while the dry season with relatively low humidity and temperature may have had an adverse effect on tick and fly populations.

In Nakhon Sawan, the overall prevalence of $A$. marginale infection was $29.8 \pm 6.5 \%(57 / 191), 6.3 \%$ by microscopy alone, which was greater than the $1.6 \%$ reported by Chaichanapunpol and Vitoorakool (1996) prior to the flooding. Nakhon Sawan is located at the junction between the North and Central regions of Thailand. The Nan, Yom and Ping rivers merge to form the Chao Phraya River in the northern part of this province, so there is routine flooding (Guglielmone, 1995) and ecological habitats are greatly modified with positive and negative influences on vector populations. This suggests that flooding in this area might enhance the survival of mechanical vectors with water-related ecologies (Patz et al., 2003). However, a relatively stable $A$. marginale prevalence of around $30 \%$, without a seasonal effect, was observed for this province in the current study. The relatively high prevalence in Nakhon Sawan was probably due to climatic conditions and management factors that favored vector populations. For example, during flooding, farmers migrate their cattle to higher ground, and some of these cattle carry ticks and tick-borne infections to areas with limited pasture capacity and thus increased cattle density in the new areas (Perez et al., 1994). Furthermore, higher host densities favor interhost transfer of ticks and tick population dynamics as ticks are more likely to find a host.

The prevalence of $A$. marginale infections in Ayutthaya, at $15.5 \%$ on average, was compatible with previous reports of $48.4 \%$ by Phrikanahok et al. (2000), and $58.0 \%$ by Sriwarothai et al. (2008). A higher infection rate was found in the rainy season $(22.3 \pm 8 \%)$ compared with the dry season $(7.8 \pm 6 \%)$. Ayutthaya is characterized by low-lying land where the Chao Phraya and $\mathrm{Pa}$ Sak rivers merge, so this area is usually flooded during rainy season and vectors therefore have adapted to the changing seasonal environment. Flood conditions lead to higher humidity that increases tick and insect vector populations. Moreover, during flooding, animals had to move to higher ground for temporary shelter, which might have brought ticks and pathogens to animals in these areas (Mohanta et al., 2011). When the flooding ended, such animals were brought back to their herds, thus contaminating the herd or farm and increasing herd-level prevalence after flooding.
Farm prevalence was greater among farms with large herds $(80 \%)$ than those with small herds $(23 \%)$, which might be explained by enzootic stability on large farms. This was supported by a relatively stable prevalence of infected animals on large farms in the dry and rainy seasons ( $25.7 \%$ and $29.8 \%$, respectively). Conversely, on small farms, the prevalence of infected animals increased from 20 to $63 \%$ from dry to rainy seasons, respectively, suggesting an unstable situation due to a limited number of animals and a lack of premune status. Alternatively, the increased prevalence during rainy season among small herds may be due to the exposure of those animals to neighboring carriers under a heavy burden of biting insect vectors (Atif et al., 2012).

Our results indicated higher prevalence among from small farms during rainy season (63\% versus 30\%), but not during dry season (around 20-25\% for both large and small farms). This could be explained again by either cattle management, which may differ according to farm size, or the environment, which may favor tickborne transmission of $A$. marginale.

Bovine anaplasmosis can be fatal in susceptible cattle. Naïve cattle over 2 years of age are usually affected by a peracute fatal form of the disease (Jones and Brock, 1966). However, in enzootic areas, such events are less likely because greater numbers of cattle are exposed to the infection during their first year. Immune dams also produce colostrum with potentially protective antibodies to $A$. marginale. This passive protection lasts about 3 months, and in most cases is followed by an age-related resistance to anaplasmosis that lasts until the cattle are 9 to 12 months old (Kocan et al., 2000). In enzootic situations, calves between 3 to 12 months of age often contract the infection and develop premunition to the clinical disease, although they may remain susceptible to superinfection upon repeated exposure to $A$. marginale (Palmer et al., 2004). In the present study, the PCR-based prevalence of A. marginale was $24 \%$ among $<1$ year-old, $39.7 \%$ among $1-5$ year-old and $18.4 \%$ among $>5$ year-old cattle. The increased prevalence from young to adult cattle may be due to a cumulative effect of infections in the age strata. However, the prevalence in the $>5$ year-old group dropped to $18.4 \%$. This observation suggested (1) that infected cattle may have been removed from the herd, by succumbing to disease or due to poor performance, (2) that older, premune cattle can maintain solid immunity, perhaps eventually clearing the infection or becoming resistant to recrudescence or superinfection, or (3) that older cattle may carry the parasite at lower levels, which were undetectable by the methods employed in this study. Notably, acquired immunity plays an important role in maintaining enzootic stability, because animals with immunity to infection and protection from clinical disease can give rise to a fully protected adult herd.

The best general linear model (Table 4) confirmed the above observation by showing the interactions between farm herd size (small or large), seasonality (rainy or dry) and the locations of the investigation (i.e. provinces). The prevalence of $A$. marginale increased with farm size and during the rainy season, compared to dry season, but with a significant effect of the province location (Nakhon Sawan versus Ayutthaya or Nan). This model suggested that cattle management practices may have differed among provinces and that these practices may have affected transmission of tick-borne parasites; such practices may influence the combined effects of environmental factors and cattle density. 
Table 4 Results of the best GLMM (with logit link function, and locality as random factor) explaining A. marginale infection (positive PCR). The initial model included the following explanatory variables: sex, age, herd size, season, location and all interaction terms, with farm as random variable. The selected model was the best model of Table 3. (Estimate of the logit function with $\mathrm{SD}=$ standard deviation; residual deviance with $\mathrm{DF}=$ degrees of freedom)

\begin{tabular}{|c|c|c|c|}
\hline Explanatory variables & Estimate (SD), $\mathrm{P}$ & $\chi^{2}, \mathrm{P}$ & Log likelihood, deviance (DF) \\
\hline \multicolumn{4}{|l|}{ province: Ayutthaya } \\
\hline vs NakhonSawan & $-0.51(2.40), 0.83$ & & \\
\hline vs Nan & 3.58 (1.33), 0.0072 & $3.21,0.20$ & \\
\hline season: dry vs rainy & $1.16(0.79), 0.15$ & $0.52,0.47$ & \\
\hline herd size & $0.09(0.04), \mathbf{0 . 0 3}$ & $6.87, \mathbf{0 . 0 0 9}$ & \\
\hline \multicolumn{4}{|c|}{ province X season: Ayutthaya dry } \\
\hline vs NakhonSawan rainy & $0.52(1.08), 0.63$ & & \\
\hline vs Nan rainy & $-3.74(1.18), \mathbf{0 . 0 0 1 6}$ & $15.49,0004$ & \\
\hline \multicolumn{4}{|c|}{ province X herd size: Ayutthaya } \\
\hline vs NakhonSawan & $0.05(0.08), 0.51$ & & \\
\hline vs Nan & $-0.09(0.08), 0.27$ & $2.27,0.32$ & $-235.9,471.8(559)$ \\
\hline
\end{tabular}

No associations $(p>0.05)$ were found between prevalence and sex. These results were consistent with previous observations (Atif et al., 2013), and indicated that $A$. marginale infection was independent of this parameter (Table 4).

After the 2011 flood, the distribution of $A$. marginale was expected to change, as a result of environmental modification and animal migration, and unusual gathering of cattle outside the flooded areas. Climate change may have an impact on the epidemiology of anaplasmosis, by affecting the distribution of ticks or population dynamics of biting insects which act as mechanical vectors. Flooding may increase the number of arthropods involved in the biological or mechanical transmission of A. marginale, and arthropod populations can rebound rapidly after extreme weather conditions (Kocan et al., 2010). Consequently, after a diapause in larval development, generated by flooding, a sudden and abundant emergence of adult biting flies may have occurred (Baldacchino et al., 2014), which was responsible for the higher than previously reported prevalence in annually flooded areas. Populations of tick species are constantly changing, and ticks may inhabit new geographical areas when livestock migrate due to flooded pastures, which in turn may contribute to the emergence of new strains of tick-borne pathogens or atypical contact between livestock, vectors and the pathogens they transmit.

In summary, this study was conducted to measure $A$. marginale prevalence in regions affected by flooding in Thailand during 2011. Effects of these floods were expected to include changes in tick and blood-sucking fly habitats. However, we found contrasted values of $A$. marginale prevalence in the three provinces, in contrast to previous studies, suggesting that, if these floods increased host exposure to A. marginale and its arthropod vectors, the observed results were dependent on local environment and cattle management practices. The prevalence of $A$. marginale was greater than previously reported from these regions, suggesting that these floods increased host exposure to this pathogen via hemotophagous arthropods. A seasonal effect was comparatively observed as a factor associated with $A$. marginale prevalence. Future work is warranted to use msp4 sequences to characterize distributions of different $A$. marginale strains in these regions, and perhaps to develop a surveillance program to identify $A$. marginale reservoir hosts in herds.

\section{Conflict of Interest}

The authors declare that there are no conflicts of interest.

\section{Acknowledgments}

This research was supported by the Center of Excellence on Agricultural Biotechnology, Science and Technology Postgraduate Education and Research Development Office, Office of Higher Education Commission, Ministry of Education (AG-BIO/PERDOCHE; PERDO/2555-01), the Science and Technology Postgraduate Education and Research Development Office, Commission on Higher Education, Ministry of Education, and the commission on Higher Education (CHE-PhD-TH) under the program Strategic Scholarships for Research Network (Ph.D. Program, Thai Doctoral degree) and by the TICA (Thailand International Cooperation Agency), under the project "Mammal trypanosomes in Thailand" and the Faculty of Veterinary Medicine, Kasetsart University.

\section{References}

Atif, F.A., Khan, M.S., Iqbal, H.J., Arshad, G.M., Ashraf, E., Ullah, S. 2012. Prevalence of Anaplasma marginale, Babesia bigemina and Theileria annulata infections among cattle in Sargodha District, Pakistan. Afr. J. Agric. Res. 7: 3302-3307.

Atif, F.A., Khan, M.S., Muhammad, F., Ahmad, B. 2013. Sero-epidemiological study of Anaplasma marginale among cattle. J. Anim. Plant Sci. 23: 740-744.

Arunyakanon, P., Teerapat, K., Dissamam R. 1966. Study of immunity of anaplasmosis vaccine in foreign breed cattle. In: Proceedings of National Conference on Agricultural Science Fifth Session: Plant and Biological Science, Animal Science and Agricultural Economics, Kasetsart University, Bangkok, Thailand, pp. 403-408.

Baldacchino, F., Desquesnes, M., Mihok, S., Foil, L.D., Duvallet, G., Jittapalapong, S. 2014. Tabanids: neglected subjects of research, but important vectors of disease agents!. Infect. Genet. Evol. 28: 596-615.

Calcagno, V., Dubosclard, M., de Mazancourt, C. 2010. Rapid exploiter-victim coevolution: The race is not always to the swift. Am. Nat. 176: 198-211. 
Carelli, G., Decaro, N., Lorusso, A., Elia, G., Lorusso, E., Mari, V., Ceci, L., Buonavoglia, C. 2007. Detection and quantification of Anaplasma marginale DNA in blood samples of cattle by real-time PCR. Vet. Microbiol. 124: 107-114.

Chaichanapunpol, I., Vitoorakool, P. 1996. Prevalence of parasitic infection in dairy cattle in Northern Thailand. In: Proceedings of $34^{\text {th }}$ Kasetsart University Annual Conference, Kasetsart University, Bangkok, Thailand, pp. 280-288.

Chethanond, U., Worasingh, R., Srinuntapunt, S. 1995. Studies on parasitic infection in dairy cattle in the south. In: Proceedings of $33^{\text {rd }}$ Kasetsart University Annual Conference, Kasetsart University, Bangkok, Thailand, pp. 398-407.

de la Fuente, J., Massung, R.F., Wong, S.J. et al. 2005a. Sequence analysis of the msp4 gene of Anaplasma phagocytophilum strains. J. Clin. Microbiol. 43: 1309-1317.

de la Fuente, J., Lew, A., Lutz, H., et al. 2005b. Genetic diversity of Anaplasma species major surface proteins and implications for anaplasmosis serodiagnosis and vaccine development. Anim. Health. Res. Rev. 6: 75-89.

Dumler, J.S., Barbet, A.F., Bekker, C.P., Dasch, G.A., Palmer, G.H., Ray, S.C., Rikihisa, Y., Rurangirwa, F.R. 2001. Reorganization of genera in the families Rickettsiaceae and Anaplasmataceae in the order Rickettsiales: unification of some species of Ehrlichia with Anaplasma, Cowdria with Ehrlichia and Ehrlichia with Neorickettsia, descriptions of six new species combinations and designation of Ehrlichiaequi and 'HGE agent' as subjective synonyms of Ehrlichia phagocytophila. Int. J. Syst. Evol. Microbiol. 51: 2145-2165.

Fungfuang, W., Ruamthum, W., Lertchunhakiat, K., Khoomsab, K., Kanjanarajit, S. 2006. Anaplasma infection in hog deers (Cervus porcinus) from HuaySai wildlife captive breeding research center in Phetchaburi province. In: Proceedings of $44^{\text {th }}$ Kasetsart University Annual Conference, Kasetsart University, Bangkok, Thailand, pp. 557-560.

Guglielmone, A.A. 1995. Epidemiology of babesiosis and anaplasmosis in South and Central America. Vet. Parasitol. 57: 109-119.

Islam, M.K., Alim, M.A., Tsuji, N., Mondal, M.M. 2006. An investigation into the distribution, host-preference and population density of Ixodid ticks affecting domestic animals in Bangladesh. Trop. Anim. Health Prod. 38: 485-490.

Jittapalapong, S., Lieowijak, C. 1988. Epidemiological survey of blood protozoa and rickettsia in dairy cow in Nong pho. In: Proceedings of $26^{\text {th }}$ Kasetsart University Annual Conference, Kasetsart University, Bangkok, Thailand, pp. 117-122.

Jones, E.W., Brock, W.E. 1966. Bovine anaplasmosis: Its diagnosis, treatment, and control. J. Am. Vet. Med. Assoc. 149: 1624-1633.

Kocan, K.M., Blouin, E.F., Barbet, A.F. 2000. Anaplasmosis control: Past, present, and future. Ann. N.Y. Acad. Sci. 916: 501-509.

Kocan, K.M., de la Fuente, J., Guglielmone, A.A., Melendez, R.D. 2003. Antigens and alternatives for control of Anaplasma marginale infection in cattle. Clin. Microbiol. Rev. 16: 698-712.

Kocan, K.M., de la Fuente, J., Step, D.J., Blouin, E.F., Coetzee, J.F., Simpson, K.M., Genova, S.G., Boileau, M.J. 2010. Current challenges of the management and epidemiology of bovine anaplasmosis. Bov. Pract. 4: 93-102.

McBurney, D.H., White, T.L. 2010. Research Methods, $8^{\text {th }}$ ed. Wadsworth Cengage Learning. Belmont, USA.

Melendez, R.D., Forlano, M. 1997. Seroprevalence and incidence of Babesiosis and Anaplasmosis in a carora breed herd from Venezuela. Rev. Bra. Parasitol. Vet. 6: 105- 109.
Mohanta, U.K., Anisuzzaman, Mondal, M.M.H. 2011. Tick and tick-Borne protozoan diseases of livestock in the selected hilly areas of Bangladesh. Int. J. Agril. Res. Innov. \& Tech. 1: 60-63.

Palmer, G.H., Knowles, D.P.Jr., Rodriguez, J.L., Gnad, D.P., Hollis, L.C., Marston, T., Brayton, K.A. 2004. Stochastic transmission of multiple genotypically distinct Anaplasma marginale strains in a herd with high prevalence of Anaplasma infection. J. Clin. Microbiol. 42: 5381-5384.

Patz, J.A., Githeko, A.K., Mccarty, J.P., Hussein, S., Confalonieri, U., de Wet, N. 2003. Climate change and infectious disease. In: McMichael A.J., Campbell-lendrum D.H., Corvalan C.F., Ebi K.L., Githeko A.K., Scherage J.D., Woodward A. (Eds.). Climate Change and Human Health, Risk and Responses. World Health Organization, Geneva, Switzerland, pp. 103-132.

Perez, E., Herrero, M.V., Jimenez, C., Hird, D., Buening, G.B. 1994. Effect of management and host factors on seroprevalence of bovine anaplasmosis and babesiosis in Costa Rica. Prev. Vet. Med. 20: 33-46.

Phrikanahok, N., Bunmatid, C., Sarataphan, N. 2000. Status and prediction of infection rate of tick fever diseases among dairy cattle in some provinces of Thailand. J. Kaset. Vet. 10: 13-23.

Richey, E.J., Palmer, G.H. 1990. Bovine anaplasmosis. Compend. Contin. Educ. Pract. Vet. 12: 1661-1668.

Sambrook, J., Fritsch, E.F., Maniatis, T. 1989. Molecular Cloning: A Laboratory Manual. Cold Spring Harbor Laboratory Press. New York, NY, USA.

Sriwarothai, J., Duangjinda, M., Pattarajinda, V., Phasuk, Y., Chaiyotwittayakun, A., Jindatajak, Y. 2008. Detection of tick-borne disease with polymerase chain reaction (PCR) in dairy TMZ. KKU. Res. J. 8: 55-62.

Stich, R.W., Rikihisa, Y., Ewing, S.A., Needham, G.R., Grover, D.L., Jittapalapong, S. 2002. Detection of Ehrlichia canis in canine carrier blood and in individual experimentally infected ticks with a $p 30$-based PCR assay. J. Clin. Microbiol. 40: 540-546.

Thaipadungpanit, J., Wuthiekanun, V., Chantratita, N. et al. 2013. Leptospira species in floodwater during the 2011 floods in the Bangkok Metropolitan region, Thailand. Am. J. Trop. Med. Hyg. 89: 794-796.

Teerapat, K., Dissamam, R. 1965. Testing on the state of carrier of the anaplasmosis disease in the Thai cattle by antigen, pp. 484-487. In: Proceeding of $4^{\text {th }}$ national conference on Agriculture and Biology Plant and Biological Science, and Animal Science section, Kasetsart University, Bangkok, Thailand.

Torti, J. 2012. Floods in Southeast Asia: A health priority. J. Glob. Health. 2: $1-6$.

Watanasin, Y. 1965. Study on immunology for anaplasmosis disease, pp. $477-$ 479. In: Proceedings of $4^{\text {th }}$ national conference on Agriculture and Biology Plant and Biological Science, and Animal Science section, Kasetsart University, Bangkok, Thailand.

Worasing, R., Rattana, S. 2007. Bovine Gastrointestinal and blood parasites in cattle in Pakpanang river basin Nakhonsithammarat province, pp. 329-338. In: Proceedings of $45^{\text {th }}$ Kasetsart University Annual Conference: Animal and Veterinary Medicine section, Kasetsart University, Bangkok, Thailand.

Yawongsa, A., Nunklang, G., Rattanakunuprakarn, J. 2010. Haematological findings in cattle infected with Trypanosomiasis, Babesiosis and Anaplasmosis during 2006-2008 at Kasetsart University Veterinary Teaching Hospital in Thailand. Kamphaengsaen Acad. J. 8: 1-6.

Zhang, Y., Bi, P., Hiller, J.E. 2008. Climate change and the transmission of vector-borne disease: A review. Asia. Pac. J. Public Health. 20: 64-76. 